NATIONAL WASTE TERMINAL STORAGE PROGRAM

PLANNING AND CONTROL PLAN

VOLUME II

PLAN DESCRIPTION

MAY 1977

"This report was prepared by Control Data Corporation, under subcontract 86Y-16535 with Union Carbide Corporation, Nuclear Division, under contract number W-7405-eng-26 with the Energy Research and Development Administration. The subcontract was administered by the Office of Waste Isolation, Union Carbide Corporation, Nuclear Division." 


\section{DISCLAIMER}

This report was prepared as an account of work sponsored by an agency of the United States Government. Neither the United States Government nor any agency Thereof, nor any of their employees, makes any warranty, express or implied, or assumes any legal liability or responsibility for the accuracy, completeness, or usefulness of any information, apparatus, product, or process disclosed, or represents that its use would not infringe privately owned rights. Reference herein to any specific commercial product, process, or service by trade name, trademark, manufacturer, or otherwise does not necessarily constitute or imply its endorsement, recommendation, or favoring by the United States Government or any agency thereof. The views and opinions of authors expressed herein do not necessarily state or reflect those of the United States Government or any agency thereof. 


\section{DISCLAIMER}

Portions of this document may be illegible in electronic image products. Images are produced from the best available original document. 
This report was prepared as an account of work sponsored by the United States Government. Neither the United States nor the Energy Research and Development Administration, nor any of their employees, nor any of their contractors, subcontractors, or their employees, makes any warranty, express or implied, or assumes any legal liability or responsibility for the accuracy, completeness or usefulness of any information, apparatus, product or process disclosed, or represents that its use would not infringe privately owned rights. 


\title{
NATIONAL WASTE TERMINAL STORAGE PROGRAM
}

\section{PLANNING AND CONTROL}

\author{
PLAN \\ VOLUME II

\section{PLAN DESCRIPTION}

This report was prepared as an account of work This repon the United Stales Govemment. Neither the Spined Sieve nor the United States Deperthent of Energy, nor any of their employes, nor any of their

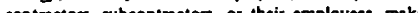
contrich, subcor any waranty, expreas or implied, or asomes any lega Lability or responasbsilly for the accuracy, completeness or usefulnes of any information, apparatus, product of process disclosed, or represents that its use would not infringe privately owned rights.

\author{
THE OFFICE OF WASTE ISOLATION
}

UNION CARBIDE CORPORATION-NUCLEAR DIVISION 
TABLE OF CONTENTS

Section

$\underline{\text { Page }}$

1.0

INTRODUCTION

$1-1$

1.1

BACKGROUND

$1-1$

1.2

NWTS PLANNING AND CONTROL PLAN OBJECTIVE

$1-1$

1.3

PURPOSE

$1-2$

1.4

SCOPE

$1-2$

2.0

PLAN DESCRIPTION

$2-1$

2.1

OVERVIEW

$2-1$

2.2

WORK BREAKDOWN STRUCTURE CONCEPT

$2-1$

2.2 .1

NWTS WORK BREAKDOWN STRUCTURE

$2-2$

2.2 .2

PROJECT SUMMARY WORK BREAKDOWN STRUCTURES (PSWBS)

$2-2$

2.2 .3 CONTRACT WORK RR.F.AKTOWN STRISTURES (CWBS)

$2-2$

2.2 .4

PROJECT WORK BREAKDOWN STRUCTURES

$2-4$

2.2 .5

NWTS WBS IDENTIFICATION NUMBERING

$2-4$

2.3

PLANNING

2-4

2. 3.1

OWI PLANNING DATA SHEET

2-7

2. 3.2

ROLLING WAVE CONCEPT

2-7

2.3 .3

SCHEDULES

2-7

2. 3.4

BUDGETING

2-9 
TABLE OF CONTENTS (Continued)

Section

$\underline{\text { Page }}$

2.4 PERFORMANCE CONTROL

$2-9$

2.4 .1

INTRODUCTION

$2-9$

2.4 .2

EARNED VALUE CONCEPT

$2=9$

2.4 .3

COST AND SCHEDULE VARIANCES

$2-10$

2.4 .4

INTERPRETATION OF EARNED VALUE RELATIONSHIPS

$2-11$

2.4 .5

TECHNICAL ACHIEVEMENT

$2-11$

2.5

STATUS REPORTING

$2-12$

2.5 .1

GRAPHIC PRESENTATIONS

$2-12$

2.5 .2

NARRATIVE REPORTS

$2-12$

2.5.3

NWTS PROGRAM/PROJECT REVIEWS

$2-13$

2.5 .4

REPORTING HIERARCHY

$2-14$

2.6

PROBLEM IDENTIFICATION

$2-14$

2.7

CONTRACTOR CONTROL

$2-16$

2.7.1

CONTROL METHOD SELECTION

$2-16$

2.7 .2

CONTROL METHOD NUMBER ONE

$2-17$

2.7 .3

CONTROL METHOD NUMBER TWO

$2-18$

2.7 .4

CONTRAĊTOR REPORTING

$2-19$

2.8

CHANGE CONTROL

$2-19$ 
TABLE OF CONTENTS (Continued)

APPENDIXES

$\begin{array}{cllc}\because & & & \\ \text { APPENDIX A } & \text { GLOSSARY OF TERMS } & \ddots & \text { A-1 } \\ \text { APPENDIX B } & \text { OWI PLANNING DATA SHEET } & & \text { B-1 } \\ \text { APPENDIX C } & \text { OWI STATUS RECORD FORM } & & \mathrm{C}-1 \\ \text { APPENDIX D } & \text { OWI STATUS REPORT } & & \vdots \\ \text { APPENDIX E } & \text { COMMITMENT STATUS REPORT } & & \text { D-1 } \\ \text { APPENDIX F } & \text { SCHEDULE STATUS REPORT } & \text { E-1 }\end{array}$

LIST OF ILLUSTRATIONS

Figure

Page

$2-1$

WBS Development

$2-3$

$2-2$

OWI Work Breakdown Structure

$2-5$

$2-3$

Planning and Control Cycle

$2-6$

$2-6$

Status Reporting/Problem Identification Concept

2-15

B-1

Sample OWI Planning Data Sheet

B-2

C-1

Sample OWI Status Record

$\mathrm{C}-2$

$\mathrm{D}-\mathrm{i}$

Sample OWI Status Report

$\mathrm{D}-2$

E-1

Sample Commitment Status Report

E-2

$\mathrm{F}-1$

Schedule Status Report

F-2 


\section{SECTION I \\ INTRODUCTION}

\subsection{BACKGROUND}

In May 1976, the Union Carbide Corporation - Nuclear Division (UCC-ND), at the direction of the Energy Research and Development Administration (ERDA) Division of Nuclear Fuel Cycle and Production (DNFCP), established the Office of Waste Isolation (OWI) to assume the responsibility for the National Waste Terminal Storage (NWTS) Program Management.

Upon assumption of the NWTS Program Management responsibility by OWI, it became evident that a Planning and Control system was integral to successful management of the NWTS Program. There were existing systems which were drawn upon in the formulation of the initial Planning and Control Plan. The ERDA Division of Reactor Development and Demonstration Performance Measurement System (RDD/PMS) was one of the principal source documents utilized in preparing the Planning and Control Plan.

\subsection{NWTS PLANNING AND CONTROL PLAN OBJECTIVE}

The objective of the NWTS Program Planning and Control Plan is to provide the information necessary for timely and effective OWI management decisions related to the NWTS Program including the formalized mechanisms for:

- Defining the NWTS program in a disciplined, structured manner from high-level summaries to discrete manageable work packages for which cost and schedule budgets can be established and performance responsibility assigned. 
- Providing program life cycle summary and detail, cost and schedule infor mation to satisfy management requirements.

- OWI internal and contractor reporting which will provide the necessary information to quantify dollars expended and work accomplished in relation to planned expenditures and progress.

- Providing OWI management with program status in terms of summary and detailed cost and schedule information.

- Timely identification of problems for management resolution.

- Providing the information necessary to satisfy reporting requirements external to OWI.

\subsection{PURPOSE}

The purpose of the Planning and Control Plan is to describe the concepts and techniques that will be utilized by OWI to establish structured, completely planned and controlled technical, cost, and schedule NWTS baselines from which performance or progress can be accurately measured.

\subsection{SCOPE}

The provisions of the Planning and Control Plan apply to all OWI organizations and their contractors, sub-contractors, and suppliers as applicable. 
SECTION TWO

PLAN DESCRIPTION

\subsection{OVERVIEW}

The NWTS Planning and Control Plan, as designed and implemented by OWI, will include the following program and project management techniques:

- Work Breakdown Structure (WBS)

- Planning (Schedules/Budget)

- Performance Control

- Status Reporting

- Problem Identification

- Contractor Control.

- Change Control

\subsection{WORK BREAKDOWN STRUCTURE CONCEPT}

The WBS technique requires the identification of the major end items of the NWTS program with successive subdivision of each end item into increasingly detailed categories and subcategories of products and work. The completed.WBS will define the total program effort in terms of manageable elements or packages of work which are the responsibility of the various OWI organizational entities. The WBS will then have identified the various levels and discrete elements of work to enable:

- The identification of any functional interfaoes that might exist between the elements.

- The scheduling of tasks in logical sequence.

- The budgeting of tasks in logical sequence.

- The budgeting of funds in consonance with task schedules. 


\subsubsection{NWTS WORK BREAKDOWN STRUCTURE}

The NWTS Work Breakdown Structure is a product-oriented task hierarchy of all the work to be performed in accomplishing the program objectives. The products are hardware, software, support services, tests, documentation, and other qualified elements. The Program Summary levels consist of Level zero, the NWTS Program, the Level 1 elements such as Program Management, Geologic Studies, Technical Support Studies, and Engineering Studies. Further definition and structuring of the work under each of the Level 1 elements produce the Project Summary Elements, normally at Level 2 through 5 depending on the subdivision of work definitions practicable from each Level 1 Program element. The number of levels in the task hierarchy depends upon the scope and complexity of the individual projects. Where the project involves contract effort, the portion of the WBS relating to the contract effort is developed in two segments: (1) the Project Summary WBS, and (2) the Contract WBS. Figure 2-1 describes the sequence of WBS development.

\subsubsection{PROJECT SUMMARY WORK BREAKDOWN STRUCTURES (FSWBS)}

Project Summary WBS will be prepared by OWI to identify the lower level elements unique to the various projects. The PSWBS will normally contain project elements through at least the third level. OWI will select project elements from the PSWBS for assignment to contractors. The contractors will then develop their Contract Work Breakdown Structures to lower level elements.

\subsubsection{CONTRACT WORK BREAKDOWN STRUCTURES (CWBS)}

A complete WBS for a contract will be developed and used by the contractor in accordance with the contract statement of work (SOW). The CWBS is comprised of, and bascd upon, the selected PSWBS elements included in the Request for Proposal and the extensions of these. elements by the contractor to cover the lower levels of the WBS. Approval of the CWBS will be negotiated by OWI with the selected contractor. The agreed upon CWBS provides the common denominator for communication between OWI and the contractor for work planning, control, and contract reporting. 
RELATIONSHIP OF THE TYPES OF WBSs

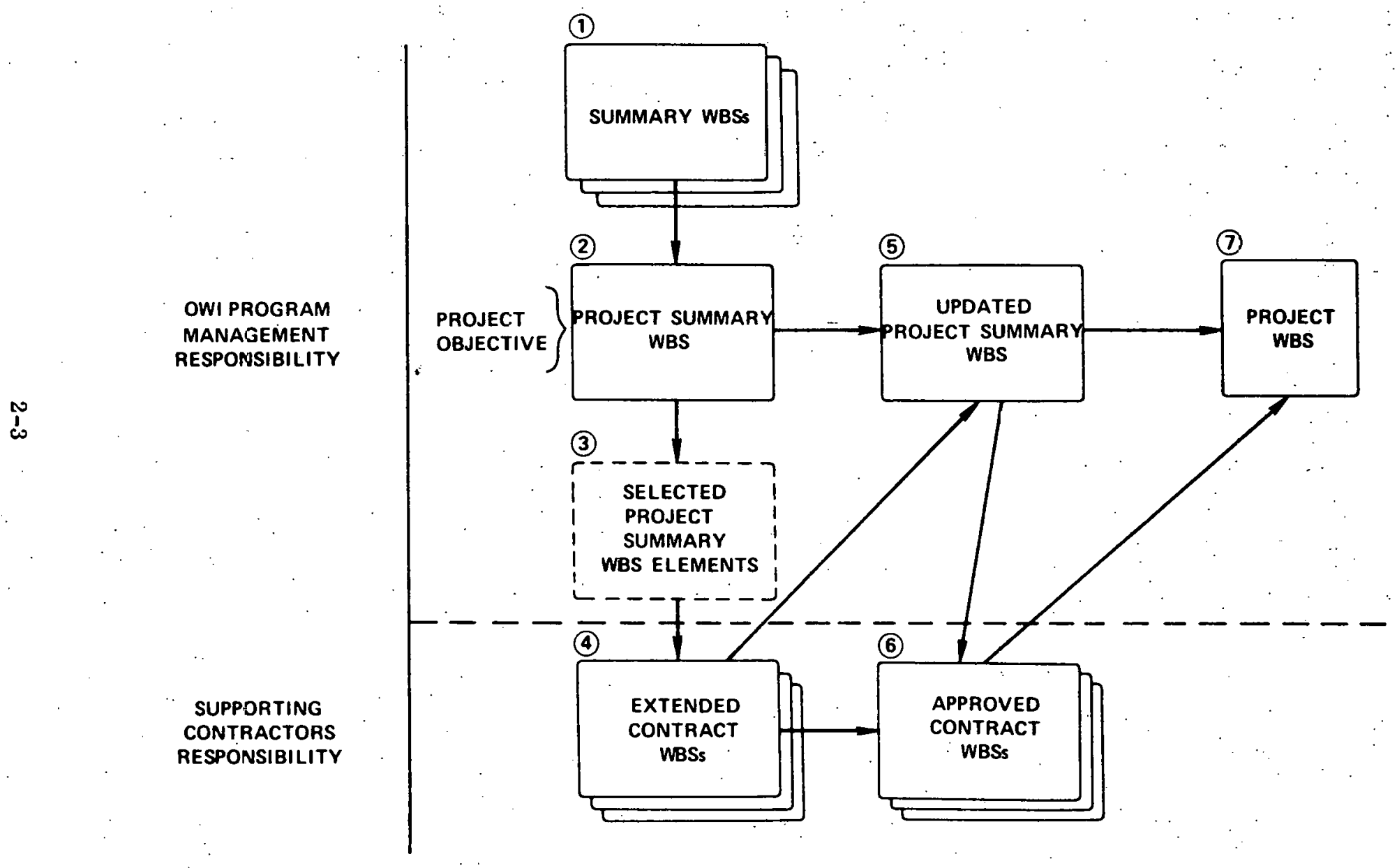

Figure 2-1. WBS Development 


\subsubsection{PROJECT WORK BREAKDOWN STRUCTURES}

OWI will construct the Project WBS by combining the approved CWBSs for all supporting contracts and the updated PSWBS. All levels of the CWBSs need not be included in the OWI Project WBS. The Project WBS will be maintained and revised to incorporate changes throughout the life of the project to ensure traceability of the work efforts. An amplification of the WBS development is contained in ERDA Handbook 0805.3 Part 1. Work Breakdown Structures, and the ERDA Reactor Development and Demonstration (RDD) Performance Measurement System WBS Guide RDD/PMS-6.

\subsubsection{NWTS WBS IDENTIFICATION NUMBERING}

Figure 2-2 defines the NWTS WBS numbering system for element identification.

A. Program/Summary WBS

The highest Program Summary WBS Level is designated Level "0" which represents the NWTS Program (1100).

The next lower Program Summary Level is designated Level 1 which contains the major program elements of the NWTS Program.

B. Project Summary Levels

The Project Summary Levels, normally 2 through 5, are obtained by further definition of the work within each element of the Program Summary Level 1. For example, as shown in figure 2-2, category 1130 is further divided into elements which include $1130 \mathrm{~A}, 1130 \mathrm{~B}$, and $1130 \mathrm{C}$. Selecting $1130 \mathrm{C}$ for further work breakdown, the Level 3 elements would include $1130 \mathrm{C} 01,1130 \mathrm{C} 02$, and $1130 \mathrm{C} 03$.

\subsection{PLANNING}

OWI will conduot the planning of the NWTS Program utilizing the WBS concept for an adequate definition of the work to be accomplished to develop schedules, budgets, and performance control. OWI has developed NWTS master schedules and associated budgets utilizing this technique. These schedules and budgets will be amplified and revised on a continuing basis as illustrated in Figure 2-3, Planning and Control Cycle. 
OWI WORK BREAKDOWN STRUCTURE (WBS)

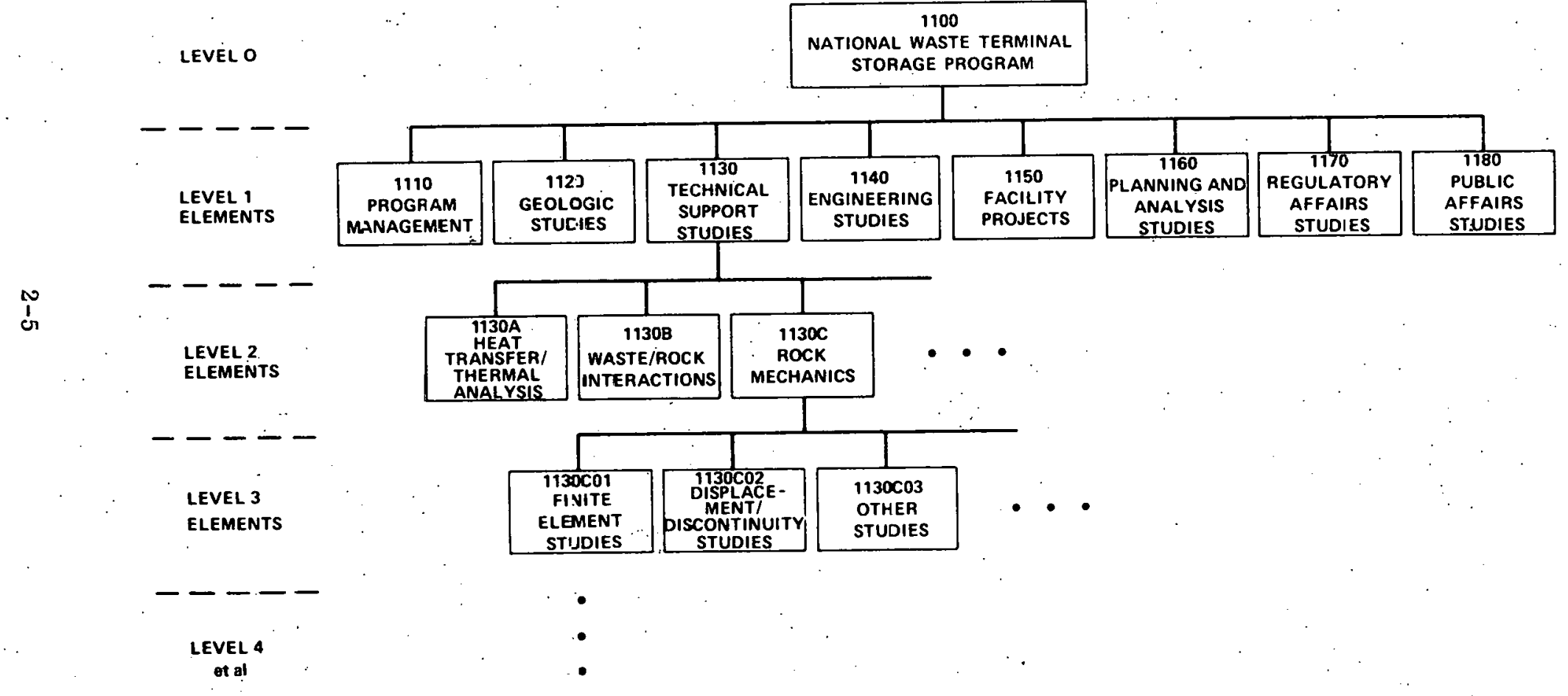

Figure 2-2. OWI Work Breakdown Structure 


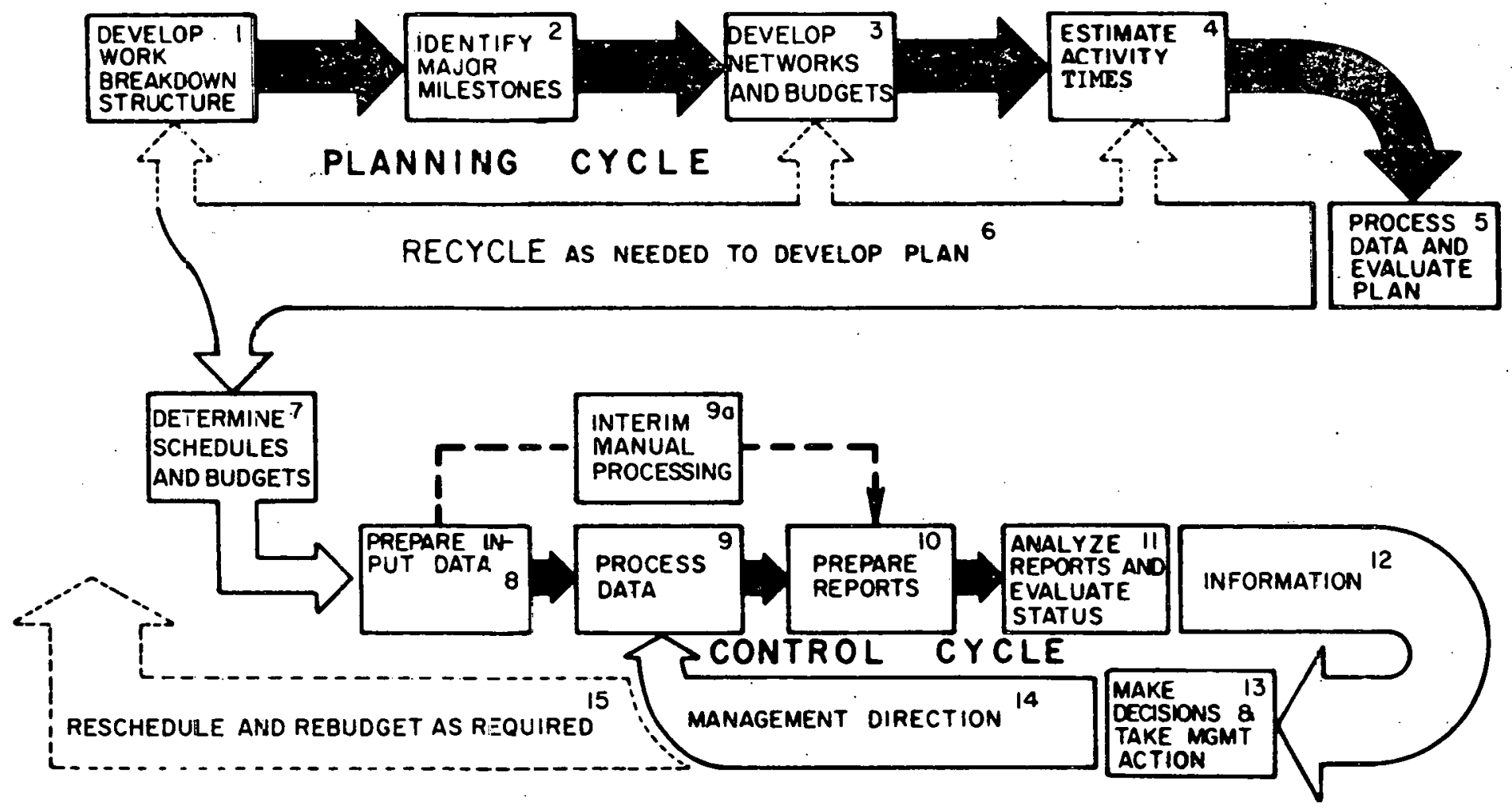

Figure 2-3. Planning and Control Cycle 


\subsubsection{OWI PLANNING DATA SHEET}

The OWI Planning Data Sheet shown in Appendix B, Figure B-1, identifies the individual work elements with their associated budgets, schedules, responsibilities, work orders, and start/stop dates. Instructions for completing the form are also contained in Appendix B.

\subsubsection{ROLLING WAVE CONCEPT}

The "rolling wave" planning concept will be used by OWI. According to this concept, work is planned in finite but sizable increments at the outset of the program. These planning increments form the basis for work authorization, budgeting, and master scheduling. As the program progresses, near term work is defined and planned in more detail. The effect of this concept will be the availability of a detailed definition for the work to be accomplished in the near term (Fiscal Year), larger elements of work defined for intermediate time periods (one to five years) and summary type detail for those time periods beyond the intermediate range.

\subsubsection{SCHEDULES}

\section{A. The WBS and Scheduling}

The WBS affords a framework for the aggregation of schedule information by WBS elements to establish overall and detailed schedules. Schedules will become progressively more accurate as plans are developed in greater detail and more information is available to OWI. The scheduling techniques that will be utilized by OWI are described in the following paragraphs.

1. Milestone Schedules

The milestone scheduling technique focuses on the sequential achievement of significant actions necessary for successful completion of the project objectives. It provides the schedules and sequential relationships among major activities and events of the project effort.

\section{Network Scheduling}

Network techniques (such as PERT and CPM) depict the interrelationships and interdependencies of the planned project activities and events and evaluate the 
critical path (sequence) of activity completion. The activities and events depicted in the network should be clearly related to both the WBS and the project milestones. The essential purpose of network methods is to develop an explicit plan for the program which recongizes the logical sequences in which the individual activities must be performed. On the basis of this plan, it then becomes possible to analyze the project in terms of the total time required and potential constraints. The network method will also be used as a control device for comparing actual progress with scheduled progress and evaluating possible corrective action if required.

3. Gantt Charts

Gantt charts identify individual task and job orders, depicting their scheduled and actual progress against time. The tasks that they depict are derived from the lowest "work package" element of the WBS. Thus, they represent the ultimate breakdown of the project work to the detailed tasks (and manpower) of a unit or individual for accomplishing the work package effort. However, the Gantt chart is essentially a reporting display chart. The milestones and events of the Gantt chart can become highly accurate schedule reports when they are based on the information provided from a network planning and control technique.

4. Line of Balance (LOB)

The Line of Balance (LOB) techniques provide a means of controlling detailed and repetitive production processes. The application of the LOB technique is almost entirely restricted to projects involved in the production and delivery of quantities of hardware, or repetitive processes on a time-phased schedule extending over a prolonged period of time.

5. Interface Milestone Management

Interface Milestone Management is a technique for identifying and managing the interface events and milestones that should be scheduled to accomplish the functional interfaces that are identified between the tasks of two or more subsystem managers. An appropriate network based planning and scheduling technique will help ensure that these highly critical events are accomplished. within schedule. 


\subsubsection{BUDGETING}

Based upon the work definition provided by WBS and the time orientation supplied by the scheduling function, OWI will prepare the necessary budgets for the NWTS Program. To fulfill the budgeting requirements, the technique to be utilized is to estimate costs at the lowest levels of the WBS and summate upwards to the required levels. Budgets will be prepared by OWI Managers in accordance with ERDA directives. Budgets will be in consonance with the U. S. Government Fiscal Years commencing in October and running through the following September, and will include three cost categories which are Construction, Capital Equipment, and Oper ating Costs.

\subsection{PERFORMANCE CONTROL}

\subsubsection{INTRODUCTION}

The fundamental elements of performance control for the successful management of a program are cost, schedule and technical performance control. In the past these parameters were controlled by a comparison of planned cost, schedule and technical progress versus actuals. This basic technique has been enhanced by the "earned value" concept, which will be utilized by OWI on the NWTS Program.

\subsubsection{EARNED VALUE CONCEPT}

This concept utilizes three measurement parameters to quantify the cost and schedule progress against planned or budgeted work, in terms of dollars. These elements are:

A. Budgeted Cost for Work Scheduled (BCWS)

This is the time-phased budget plan (baseline) which represents the contract work plan.

B. Budgeted Cost for Work Performed (BCWP)

This is referred to as the "earned value" or the planned value for work performed.

C. Actual Cost for Work Performed (ACWP)

This parameter consists of the direct and allocated indirect costs applicable to the contract. 
The relationship of these parameters to the terminology utilized by OWI or the OWI Status Record, shown in Appendix C, Figure $\mathrm{C}-1$, is as follows:

Eäned Value Concept

BCWP

BCWS

ACWP

\section{OWI Status Record}

Work accomplished

Work scheduled

\$ Spent

\subsubsection{COST AND SCHEDULE VARIANCES}

\section{A. Cost Variances}

Utilizing the "earned value" technique, cost variances are computed by subtracting the ACWP (Actuals) from the BCWP (Progress) with the answer being in a positive or negative variance. Thresholds of acceptable cost variances for each reporting level will be established by OWI, thereby facilitating the management by exception technique.

B. Schedule Variances

Schedule Variances will be measured utilizing both the "earned value" concept (dollars) and normal "time" status measurement techniques. This is necessitated by the fact that "dollar" only controls may obscure work sequence problems and failure to meet specific milestones.

\section{Schedule Variances - Dollaiss}

Utilizing the "earned value" concept, schedule variances in terms of dollars will be calculated by subtracting the BCWS (Plan) from the BCWP (Progress) with the answer being in a positive or negative schedule variance. Thresholds of acceptable variances will be established by OWI management.

2. Schedule Variances - Time

OWI will utilize various scheduling techniques to establish the status of schedules in terms of time. These will include milestone charts, schedule narratives, networks (PERT/CPM), Gantt charting and Line of Balance. 


\subsubsection{INTERPRETATION OF EARNED VALUE RELATIONSHIPS}

The following table provides examples of the management visibility afforded OWI by utilizing the "earned value" concept.

\begin{tabular}{ccc}
$\begin{array}{c}\text { Schedule } \\
\text { Variance }\end{array}$ & \multicolumn{2}{c}{$\begin{array}{l}\text { Cost } \\
\text { Variance }\end{array}$} \\
$\begin{array}{ccc}\text { BCWS } \\
\$ 1\end{array}$ & $\frac{\text { BCWP }}{\$ 1}$ & $\frac{\text { ACWP }}{\$ 1}$ \\
$\$ 2$ & $\$ 2$ & $\$ 1$ \\
$\$ 1$ & $\$ 1$ & $\$ 2$ \\
$\$ 1$ & $\$ 2$ & $\$ 2$ \\
$\$ 1$ & $\$ 2$ & $\$ 3$ \\
$\$ 1$ & $\$ 2$ & $\$ 1$ \\
$\$ 3$ & $\$ 2$ & $\$ 1$ \\
$\$ 2$ & $\$ 1$ & $\$ 3$ \\
$\$ 2$ & $\$ 1$ & $\$ 1$
\end{tabular}

Schedule Variance $=$ BCWP - BCWS

Cost Variance $=$ BCWP - ACWP

\subsubsection{TECHNICAL ACHIEVEMENT}

A key to effective cost/schedule control is correlation of technical achievement with accomplishment of the work effort. If the Project Summary Work Breakdown Structure (PSWBS) and associated Contractor Work Breakdown Structures (CWBS) or contractual tasks, properly define the project and tasks, correlation is greatly simplified. In correlating cost, schedule, and technical performance, it is apparent that unfavorable cost or schedule conditions may be caused by technical difficulties. When this is the case, the quantitative information the contractor reports will be supplemented by narrative to explain the technical problem and its impact. 
As work on a contract progresses, the contractor will be required to determine the adequacy and quality of the work performed by inspections, tests, or other types of technical measurements. If the results are satisfactory and no corrective action is required, the work will be allowed to proceed. If, on the other hand, deficiencies are found, the contractor will be required to analyze the various alternatives for corrective actions, e.g. , redesign, scrap and remake, and rework. When considering these alternatives, the cost and schedule impact must be weighed in addition to the technical considerations. After one of the alternatives is selected as the desired course of action to correct the deficiencies, it will become necessary to plan the additional work and to change the schedules affected. In some cases, OWI may choose to provide additional budget to the responsible organization. Thus, there is a close relationship between technical achievement, as determined by inspection and. test, and its impact on costs and schedules.

\subsection{STATUS RE PORTING}

Numerous media forms will be utilized by OWI to provide the various levels of management with the information necessary to enhance the decision making process. The se will include graphic presentations, narrative reports and program/project reviews.

\subsubsection{GRAPHIC PRESENTATIONS}

Various graphic displays will be utilized by OWI. Samples are illustrated in Appendixes D \& E.

\subsubsection{NARRATIVE REPORTS}

A. Cost, Schedule, Technical Status Reports

Narrative reports will be provided by contractors and the various levels of OWI management concerning cost, schedule and technical performance. As a rule these reports will describe the significant accomplishments during this reporting period and a forecast of the significant events to be completed during the next twelve weeks. An assessment of the current cost and schedule position will be included. 
B. Problem Analysis Report

Cost and schedule variance tolerances will be established by OWI management at the various reporting levels. When these acceptable tolerances are exceeded, a Problem Analysis Report will be completed by the responsible organizational entity. OWI will develop the Problem Analysis Report based upon the following criteria for the information to be included:

- Identification of the problem

- The affected WBS element or the contracted task title and number

- The schedule date for completion of the milestone

- The estimated completion date for the subject milestone

- An analysis of the problem and its cause

- Total impact assessment if the problem is not corrected (The project management network should be referenced)

- The corrective action to be implemented

- A revised completion date for the milestone based upon the corrective action

- Person responsible for implementation of the corrective action

- Person(s) reviewing and approving the Problem Analysis Report.

\subsubsection{NWTS PROGRAM/PROJECT REVIEWS}

A. Office of Waste Isolation

On a regular basis, OWI management will convene for a gener al review of the NWTS Program. The main focus of the review.will be the thorough analysis of the new information provided by the latest monthly reports developed in accordance with the procedures above. Unresolved problems and decision requirements identified in earlier reviews will also be analyzed in light of the latest infor mation. 


\section{B. External}

1. UCC-ND Program Reviews

The Director of OWI will conduct program reviews for reporting the accomplishments and prospects of the NWTS Program to the management of the Union Carbide Corporation - Nuclear Division.

2. Other Program Reviews

OWI will also plan and conduct program reviews for ERDA officials and other organizations as required.

\section{Contractor Reviews}

Certain contractors will be required to conduct status reviews for OWI management, and may, at the request of OWI, be asked to participate in the reviews defined above.

\subsubsection{REPORTING HIERARCHY}

Figure 2-4 portrays a simplified diagram of the reporting hierarchy and technique to be utilized by OWI. The objective of this technique is to simplify to the extent possible the management decision process by allowing each level of management to focus attention on defined exceptions. It is also evident from the diagram that the amount of detail is reduced by the summation process at each higher level of management. By utilizing this approach each level of the management structure is provided the optimal amount of information for his area of responsibility, with the capability to be provided with additional details as required.

\subsection{PROBLEM IDENTIFICATION}

OWI managers will utilize the management by objectives and the management by exception techniques. OWI managers will establish variance tolerances for use by OWI management and contractors. When status reporting in the system's hierarchy indicates variances exceeding tolerances, a Problem Analysis Report will be completed.

To explain the concept in greater detail, figure 2-4 shows that the OWI Status Record is the basic document to be used by OWI managers and contractors in identifying problem areas. 


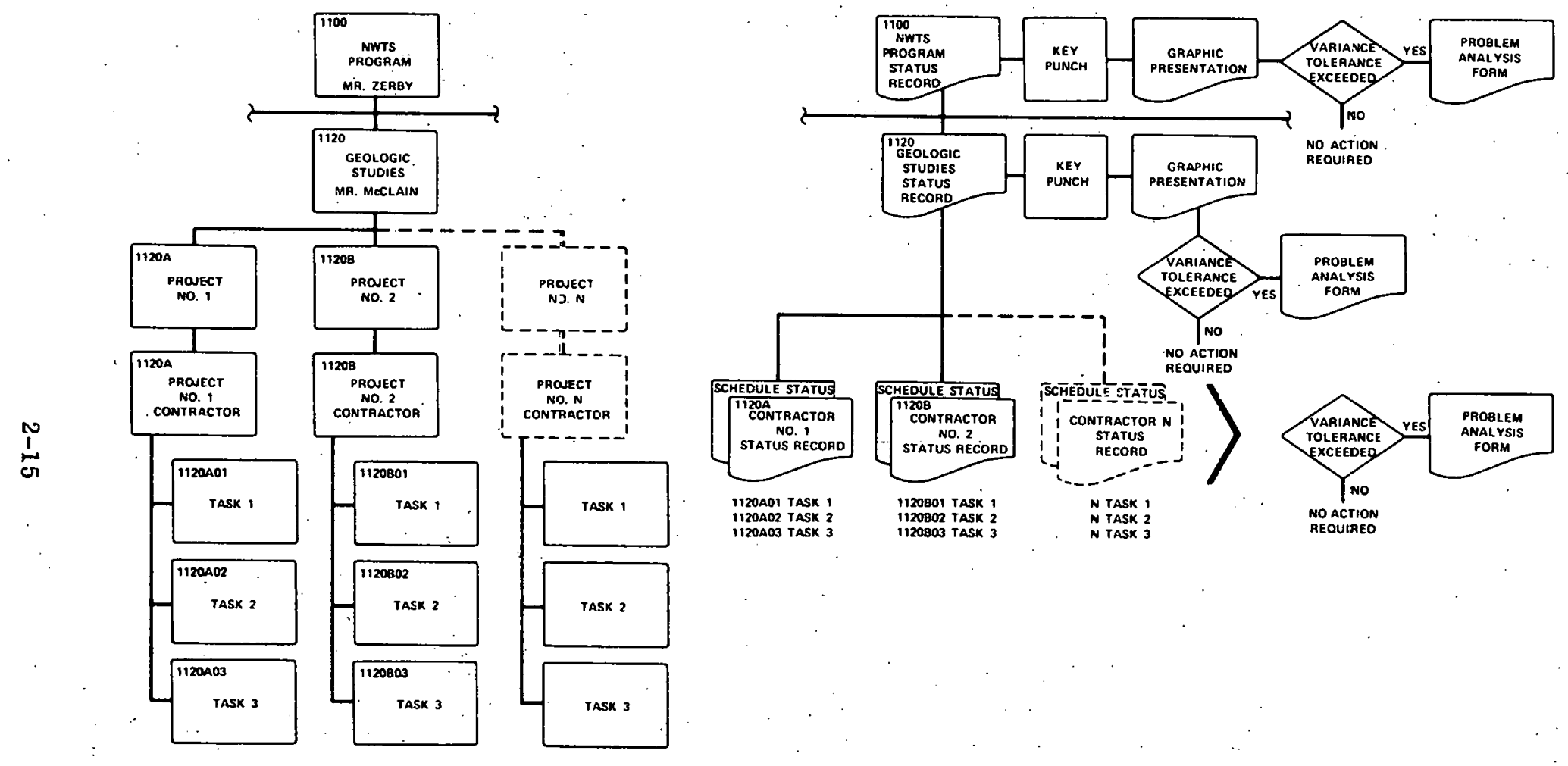

Figure 2-4. Status Reporting/Problem Identification Concept 
OWI managers will establish variance tolerances for use internally by OWI and by contractors. When Status Records are submitted by contractors to OWI and variance tolerances in their contracts are exceeded, they will be accompanied by a completed Problem Analysis Report. The Problem Analysis Report will identify the problem for OWI managers, provide an analysis of the problem and a recommended solution when feasible. Similarly, when OWI Status Reports are aggregated within OWI and the variances exceed the tolerances acceptable to a manager, the manager at the level at which the tolerance is exceeded will complete a Problem Analysis Report. This Problem Analysis Report will be submitted to the next level of management within OWI. In the case of the Director, OWI, the information in the Problem Analysis Report may be utilized for external reporting.

\subsection{CONTRACTOR CONTROL}

During the life cycle of the NWTS Program numerous contractors will be solicited to provide a great variety of services. In order that OWI can exercise sufficient control over contractor performance, it is mandatory that the individual contractor's planning and control system be interfaced into the NWTS system.

The following paragraphs define the mechanisms to be utilized by OWI for the management control of all contracted efforts. OWI will exercise one of two methods of control based upon the envisioned contract type, dollar value, and criticality to the NWTS Program. The major difference between the two methods is the level of control required to provide cost/offective management visibility.

\subsubsection{CONTROL METHOD SELECTION}

Each proposed contracted effort will be reviewed by OWI management to establish the control method that is applicable.

The criteria for this selection process is:

- Contracts with a total value in excess of $\$ 500,000$.

- Contracted efforts that are of a technical or schedule nature critical to the NWTS Program as asscssed by OWI management. 
- As specifically directed by the OWI Program Director or his designated representative(s).

- Contracts other than fixed price or fixed price with escalation. All other contracts including fixed price incentives are candidates for detailed control.

\subsubsection{CONTROL METHOD NUMBER ONE}

In-depth control will be exercised by OWI for those contracts that are of type, expenditure level, and/or criticality to the NWTS Program are established by the defined criteria, to warrant detailed OWI management visibility. In these instances OWI will specify in the Request For Proposal (RFP) that the contractor must adhere to the major concepts and techniques of the NWTS system described in this manual and report status utilizing the OWI forms at control levels approximating $\$ 50,000$ and 3 months duration. This status information will be integrated into the NWTS system.

For those contracted efforts that are selected for the utilization of control method number one the following methodology will be implemented by OWl.

A. Project Summary Work Breakdown Structures (PSWBS)

OWI will be responsible for preparing the PSWBS to be included in the Request For Proposal to,identify the work to be accomplished by the successful bidder. The PSWBS will normally define 3 to 4 levels of detail in order not to be unduly restrictive as concerns the proposer's organizational structure and normal methods of work accomplishment.

B. Contract Work Breakdown Structure (CWBS).

The RFP will instruct the competing contractors to extend the PSWBS as low as necessary to identify and structure the work effort to achieve the purpose of the eventual contract. This breakdown should be to manageable subtask entities approximating $\$ 50,000$ and 3 months duration. The prospective contractors will be allowed to suggest changes to the PSWBS to enhance the effectiveness of the 
CWBS in satisfying the contract objective. The CWBS as proposed by the prospective contractors will be a part of the OWI proposal evaluation process.

C. Project Work Breakdown Structure (PWBS)

The successful bidder's CWBS will be negotiated as required by OWI in consonance with the initial PSWBS. The purpose of this negotiation is to firmly establish the PWBS for the contract. Any subsequent changes to the negotiated PWBS will be formally controlled utilizing the change control mechanisms described in this section.

\subsubsection{CONTROL METHOD NUMBER TWO}

Those contracts that do not warrant in-depth OWI management visibility based upon the defined criteria, will be controlled at significantly higher levels of expenditures and task durations. These contractors will still be required to utilize the OWI status reporting forms to facilitate inclusion of the performance information in the NWTS system.

The rationale for this variable level of control approach is that a major ity of the contract dollars and critical tasks will be awarded to relatively few contractors. Utilizing the two alternative methods, OWI can focus their management attention on the few relatively few contracts to exercise in-depth control over the majority of NWTS costs and mission critical efforts. The remaining contr acts will receive the level of management attention warr anted by their nature.

For those proposed contracted efforts which are not selected for in-depth OWI management visibility based upon the defined criteria, the following methodology will be utilized by OWI.

A. Project Work Breakdown Structure

The PWBS will be defined by OWI and utilized to develop the statement of work (SOW) in the RFP. The SOW may vary from a single element or work to a definition of the contract objective and a number of sub-tasks. The proposer's response to the SOW will be utilized in the OWI evaluation process. 


\subsubsection{CONTRACTOR REPORTING}

Regardless of the method of control selected by OWI for a particular contracted effort, the contractor reporting requirements are identical. Only the level of reporting is variable between the two methods.

A. OWI Status Record Form

The contractor will provide to OWI monthly OWI Status Record Form(s), Appendix C, Figure $\mathrm{C}-1$, depending upon the defined control level(s). The instructions for completing this form are defined in Appendix $C$.

B. Schedule Status Report.

Schedules will be prepared for each work element to the level(s) agreed to by OWI and the contractor, and reported upon monthly, utilizing the Schedule Status Report in Appendix F, Figure F-1.

C. Narrative Reports

The OWI Status Record Form(s) and Schedule Status Report, submitted on a monthly basis by the contractor, will be accompanied by a narrative report describing the progress of the previous month and a forecast of the significant events to be completed during the next twelve weeks. An assessment of the current cost and schedule position will be included.

D. Problem Analysis Reports

Tolerances will be established by OWI, in conjunction with the contractor, for acceptable variances from planned schedules and budgets. Both the OWI Status Record Form and Schedule Status Report provide for monthly variance quantification. In those instances where the variance tolerance is exceeded, the contractor will provide OWI with a Problem Analysis Report as previously described.

\subsection{CHANGE CONTROL}

All of the previous paragraphs in this section have described the concepts and techniques that will be utilized by OWI to establish structured, completely planned and controlled. 
technical cost, and budget NWTS Program baselines, from which performance or progress can be accurately measured. If the integrity of the system is to be maintained, any changes to the baselines must be incorporated in a disciplined manner. The eventual change control procedure will be an integral part of the NWTS Program Configuration Management Plan. 
A P P ENDIXES 


\section{APPENDIX A}

\section{GLOSSARY OF TERMS}

ACTUAL COST OF WORK PERFORMED (ACWP)

ACTUAL DIRECT COSTS

APPORTIONED E FFORT

BUDGETED COST FOR WORK PERFORMED (BCWP)

BUDGETED COST FOR WORK SCHEDULED (BCWS)

CONTRACTOR

COST VARIANCE

EARNED VALUE

LEVEL OF EFFORT (LOE)

SCHEDULE VARLANCE

\section{VARIANCES}

The costs actually incurred and applied or distributed in accomplishing the work performed within a given time period.

Those costs identified specifically with a contract, based upon the contractor's cost identification and accumulation system as accepted by OWI.

Effort (e.g. , Quality Assurance) that by itself is not readily divisible into short-span work packages but which is related in direct proportion to a specific measured effort.

The sum of the budgets for completed work packages and completed portions of open work packages, plus the appropriate portion of the budgets for level of effort and apportioned effort.

The sum of the budgets for work packages, planning packages, etc. scheduled to be accomplished (including in-process work packages), plus the level of effort and apportioned effort budgeted for the relevant time period.

An entity in private industry which enters into contracts with the Government or another entity in private industry.

The difference between BCWP and ACWP. At any point in time, it shows whether the work actually performed has cost more or less than that budgeted.

The budgeted cost for work performed.

Support type effort (e.g., vendor liaison) that does not readily lend itself to measurement of discrete accomplishment. It is generally characterized by a uniform rate of activity over a specific period of time.

The difference between BCWP and BCWS. At any point in time it represents in dollars the difference between work actually pertormed (accomplished) and work scheduled to be accomplished.

(See Cost Variance and Schedule Variance) 
WORK BREAKDOWN STRÜCTURE

WORK PACKAGES
A product-oriented family tree division of hardware, software, facilities, and other items which organizes, defines, and displays all of the work to be performed in accomplishing the project objectives.

1. Project Summary Work Breakdown Structure (PSWBS)

A summary WBS tailored by project management to the specific project with the addition of the elements unique to the project. Generally, the PSWBS will identify project elements through the third level.

2. Contract Work Breakdown Structure (CWBS)

The complete WBS for a contract developed and used by a contractor in accordance with the contract work statement.

3. Project Work Breakdown Structure (PWBS)

A combination of the approved CWBSs for all support ing contracts and the updated PSWBS. All levels of the CWBSs need not be included in the OWI Project WBS.

Detailed short-span jobs, or material items identified by the contractor for accomplishing work required to complete the contract. A work package has the following characteristics:

1. It represents units of work at levels where work is performed.

2. It is clearly distinguished from all other work packages.

3. It is assignable to a single organizational element and cost account.

4. It has scheduled start and completion dates and, as applicable, interim milestones all of which are representative of physical accomplishment.

5. It has a budget or assigned value expressed in terms of dollars, manhours, or other measurable units. 
6. Its duration is limited to a relatively short span of time or it is subdivided by discrete milestones to facilitate the objective measurement of work performed.

7. It is integrated with detailed engineering, manufacturing, or other schedules. 


\section{APPENDIX B}

\section{OWI PLANNING DATA SHEET}

The OWI Planning Data Sheet, Figure B-1, identifies the individual work elements with their associated budgets, schedules, responsibility, work orders, and start/stop dates. The following instructions are provided for completing the Sheet.

1. I PROJECT AREA (OWI DEPARTMENT), Area (1)

Enter the name of the department which originated the document.

2. II PROJECt TITLE, Area (2)

Enter the title of the task.

3. III OBJECTIVE (What by when), Area (3)

State end purpose and completion date of task:

4. IV ASSUMPTIONS (Including budget case), Area (4) Include any programmatic assumptions defined by Planning and Analysis, plus any specific project assumptions.

5. V SUBTASKS, Area (5

List elements of the project in the left column. Ilustrate by bar charting the schedule for the various elements, as illustrated by the example. Elements to the right of a vertical line cannot be started before elements to the left have been completed. Slack time is illustrated by a dashed bar.

6. INCURRED $\$ K$, Area 6

Enter estimate of actual expenditures by year. Identifies the funding category associated with the incurred cosits. A separate form should be attached to identify supporting funding schedules.

7. MILESTONE NO., Area (7)

I.ist the milestones identified on the bar chart. Provide a description of the event and a description of the relationship of the milestone to other milestones within the given project or other NWTS projects. 


\section{OWI PLANNING DATA SHEET}

(1) I. PROJECT AREA (OWI Department): Planning and Analysis

(2) II. PROJECT TITLE: Transportation/Logistics Study (R1)

(3)II. OBJECTIVE (What by when): Define ERDA's role in the surface transportation of waste and provide computer simulation of the transportation system.

(4)IV. ASSUMPTIONS (Inicluding budget case):

1. Base Program Assumptions

2. Contract with ORNL

(5) V. SUBTASKS

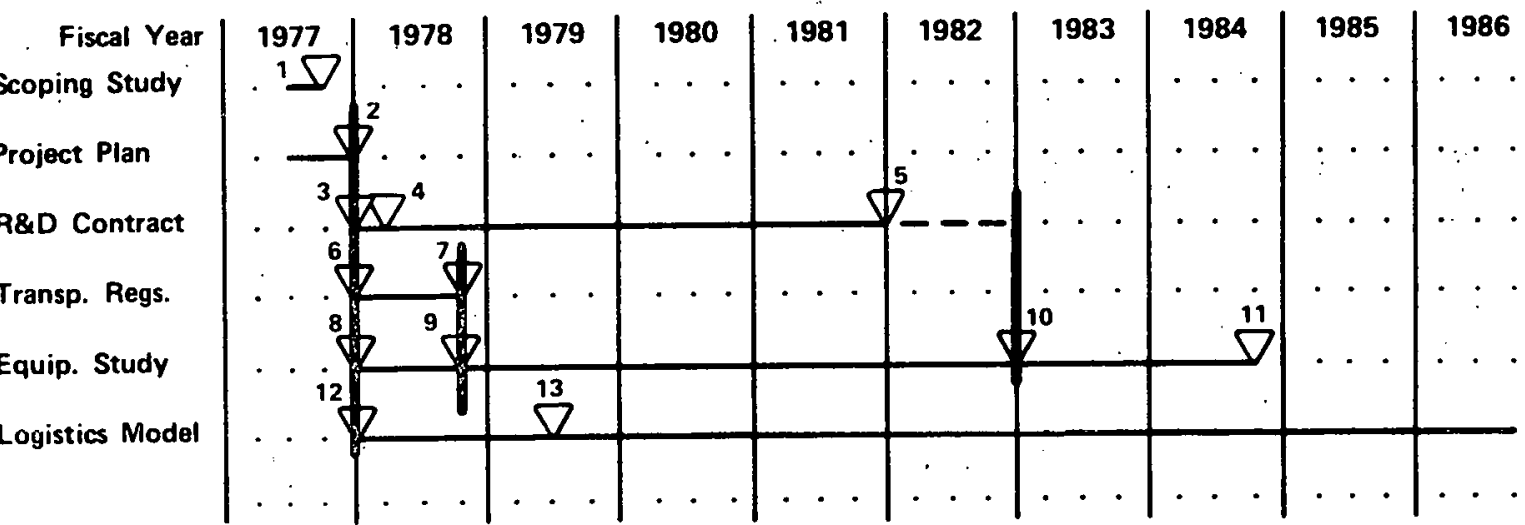

(6) Incurred Costs. (SK)

Capital Equipment Capital Construction

(7) Milestone No.

1.

Scoping study complete

2.

3.

4.

5.

6.
Program plan complete

RFPs started

RFPs written

Support R\&D complete

Transportation Regulations study started

8) VI. OTHER RESOURCES REQUIRED (Including equipment):
(3) WBS Number
(10) File Number
(11) Prepared by
(12) This
Replacos
1160D01
2-7.7/001
JEV
Date: $2 / 28 / 77$
Page: 1 of 2
1-17-77
1 of 2

Information required for Cask Design,

Required for R\&D Contracts, and Transportation Regulations ond Equipment Study.

$100 \%$ of Project Plan

Required for Equipment Study, Federal Agencies $100 \%$ of Project Plan 


\section{OWI PLANNING DATA SHEET}
I. PROJECT AREA (OWI Department):
II. PROJECT TITLE:
III. OBJECTIVE (What by when):
IV. ASSUMPTIONS (Including budget case):
V. SUBTASKS
Incurred Costs (\$K)
Fiscal Year

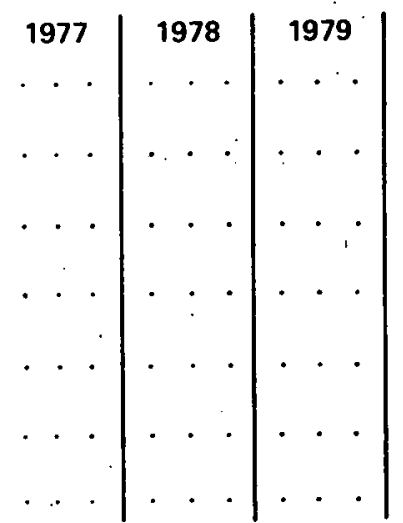

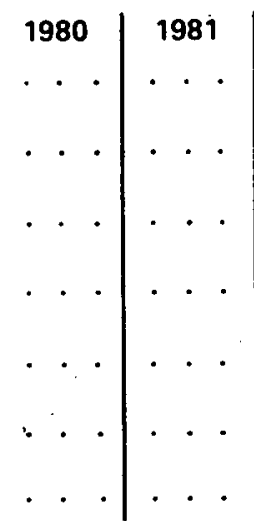

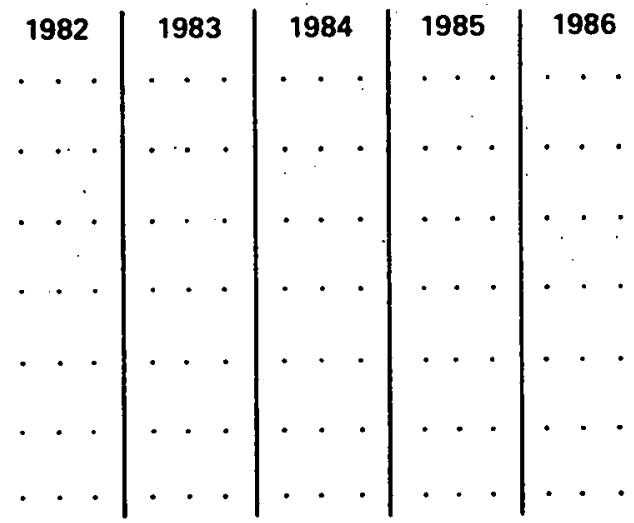
Operating
Capital Equipment
Capital Construction
Milestone No.
7.
8.
9.
10.
11.
12.
13.

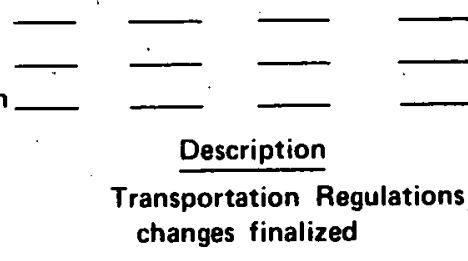
Start Equipment Study
Equipment requirements defined
Equipment designed
Equipment procurement support completed
Start logistics model
Baseline model operational

VI. OTHER RESOURCES REQUIRED (Including equipment):

WBS Number

1160nก1
Flle Number

$2-77 / 001$
Prepared by

JEV
This

Date: $2 / 28 / 77$

Page: 2 of 2

Figure B-1. Sample OWI Planning Data Sheet (Page 2 of 2) 
8. VI OTHER RESOURCES REQUIRED (Including equipment), Area (8) List any other resources not identified in the cost analysis.

9. WBS NUMBER, Area (9) Assigned by Planning and Analysis.

10. FILE NUMBER, Area (10 Assigned by Planning and Analysis.

i1. PREPARED BY, Area (11) Initials of the originator.

12. THIS REPLACES, Area (12) Identify date of the current issue and reference any prior version which it replaces. 


\section{APPENDIX C}

\section{OWI STATUS RECORD FORM}

The basic tool in the system for depicting the technical progress of the NWTS program is the "OWI Status Record", a sample of which is shown in Figure C-1. One of these records shall be maintained for each task by the cognizant task manager. It must be noted that data recorded on the OWI Status Record Form represents operating equipment and construction. funds. This section gives explicit instructions for filling out the Status Record Form.

\section{A. OPENING THE RECORDS}

The following steps are to be followed to initiate a record.

1. "TASK DESCRIPTION" and "DATE"

a. Enter the WBS number of the task and its descriptive title.

b. Enter the date and the current year.

2. "WORK ACCOMPLISHED", Area (1)

a. In the first column list all WBS elements defined for the task, which are called "sub-tasks".

b. Note that in the OWI system, more than one work order may accumulate for one task, but a single work order will never be divided between two or more tasks.

c. In the "PRIOR CUM" column, enter the cumulative budgeted costs for work performed on the total task and for each of its sub-tasks, through the preceding September. These numbers will be entered from the "ITD" column for September from the completed OWI Status Record for the preceding fiscal year. (At the beginning of fiscal year 1977 only, this data will be extracted from other records if necessary.)

3. "WORK SCHEDULED", Area (2)

a. In the first column, list the sub-task numbers.

b. In the "PRIOR CUM" column, enter the cumulative budgeted cost for work scheduled, for the total task and by sub-task, through the preceding 


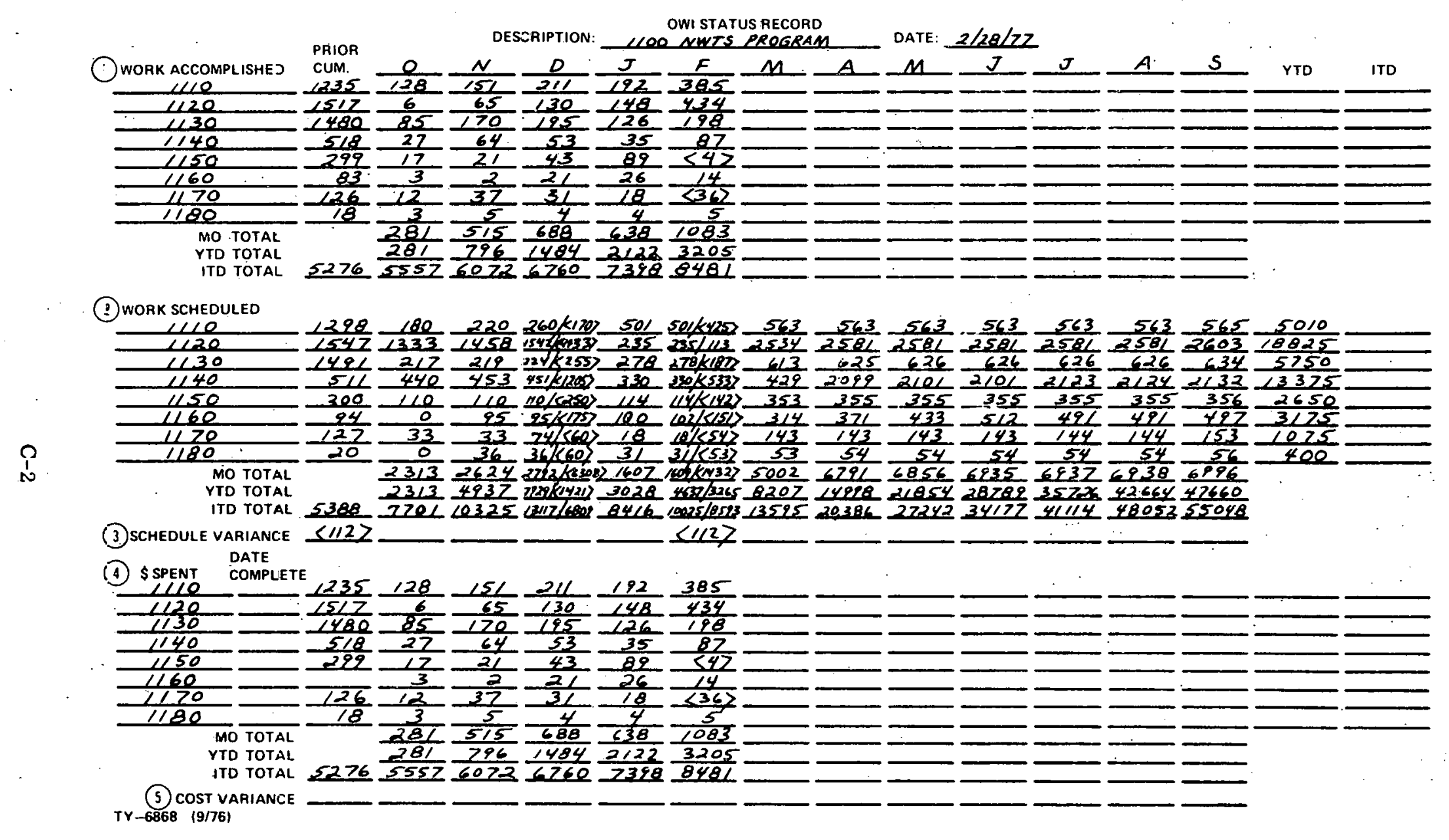

Figure C-1. Sample OWI Status Record 
September. These numbers can be found in the "ITD" column for September on the completed OWI Status Record for the preceding fiscal year. (At the beginning of fiscal year 1977 only, this data will be extracted from other records if necessary.)

4. "SCHEDULE VARIANCE", Area (3)

a. In the "PRIOR CUM" column, enter the accrued Scheduled Variance value for the total task through the preceding September. This number can be found in the "ITD" column for September on the completed OWI Status Record for the preceding fiscal year. (At the beginning of fiscal year 1977 only, this data will be extracted from other records if necessary.)

5. "\$ SPENT", Area (4)

a. In the first column, list the sub-task numbers.

b. In the "PRIOR CUM" column, enter the cumulative actual costs of work performed on the total task and by sub-task, through the preceding September. This number can be found in the "ITD" column for September on the completed OWI Status Record for the preceding fiscal year. (At the beginning of fiscal year 1977 only, this data will be extracted from other records if necessary.)

6. "Cost VARIANCE", Area (5)

a. In the "PRIOR CUM" column, enter the accrued cost variance value for the total task through the preceding September. This number can be found in the "ITD" column for September on the completed OWI Status Record for the preceding fiscal year. (At the beginning of fiscal year 1977 only, this data will be extracted from other records if necessary.)

\section{B. MAINTAINING THE RECORDS}

The following steps are to be followed to update the records.

1. "TASK DESCRIPTION" and "DATE"

a. Change the date to the date of updating.

$$
\mathrm{C}-3
$$




\section{2. "WORK ACCOMPLISHED", Area (1)}

a. In the appropriate monthly column, enter the budgeted cost for work performed during the month, by sub-task.

b. For each sub-task, add together the monthly budgeted costs in the fiscal year, to date; and enter the cumulative total in the "YTD" column for the latest month. However, October YTD costs are invariably a repetition of the MO. costs for October.

c. Add the YTD values just computed to the PRIOR CUM. values, by sub-task; and enter these sums in the ITD column for the month.

3. "WORK SCHEDULED", Are:a(2)

a. In the appropriate monthly column, enter the budgeted cost for work scheduled to be accomplished during the month, by sub-task.

b. For each sub-task, add together these monthly budgeted costs in the fiscal year, to date and enter the cumulative total in the "YTD" column for the latest month. However, October YTD costs are invariably a repetition of the MO. costs for October.

c. Add the YTD values just computed to the PRIOR CUM. values, by sub-task; and enter the sub-task sums in the ITD column for the month.

4. "SCHEDULE VARIANCE"., Area (3)

a. Subtract the WORK SCHEDULED ITD total from the WORK ACCOMPLISHED ITD total, by month; and enter the differences in their respective columns. Denote any negative value by enclosing the number in parentheses.

5. :\$ SPENT", Area (4)

a. In the appropriate monthly column; enter the actual cost of work accomplished during the month, by sub-task.

b. For each sub-task, add together its monthly actual costs in the fiscal year to date; and enter the cumulative total in the "YTD" column for the latest month. October YTD costs invariably repeat the MO. costs for October. 
c. Add the YTD values just computed to the PRIOR CUM. values, by sub-task; and enter these sub-tasks in the ITD column for the month.

6. "COST VARIANCE", Area (5)

a. Subtract the \$SPENT ITD total from the WORK ACCOMPLISHED ITD total, by month; and enter the differences in their respective columns. Denote any negative value by enclosing the number in parentheses.

7. DAte COMPlete, Area (6)

a. When a task is completed, enter the date of completion in the second column, DATA COMPLETE. 


\section{APPENDIX D}

\section{OWI STATUS REPORT}

The OWI Status Report, Figure D-1, shows the monthly year-to-date (YTD), and inceptionto-date (ITD) of the sub-tasks (except the lowest level tasks) being monitored. Data talien from the OWI Status Record is transferred to coding sheets to facilitate computer production of the graphical portion of the output. The graph shows the accumulated schedule, accumulated accomplished work, and accumulated expenditure from (hypothetically) October to April for Construction, Capital Equipment, and Operating Cost expenditures. The schedule variance is determined by subtracting the "Work Scheduled" from the "Work Accomplished". The Cost Variance is determined by subtracting the "Dollars Spent" from the "Work Accomplished". In the FY77 Increment column, the total budget is shown broken down into operating, construction, and capital expenditures. 
OWI STATUS REPORT

DATE 2/77

DESCRIPTION: 1100 NWTS PROGRAM

WORK ACCOMPLISHED

WORK SCHEDULED

$\$$ SPENT

SCHEDULE VAR.

COST VARIANCE

\begin{tabular}{ccc}
$\begin{array}{c}\$ \text { COST } \\
\text { THIS }\end{array}$ & \multicolumn{2}{c}{ (P CE AND OPERATING) } \\
MONTH & YTD. & ITD \\
$\frac{1,083}{177}$ & $\frac{3,205}{3,205}$ & $\frac{8,481}{\frac{8,593}{8,083}}$ \\
$\frac{\frac{8,481}{906}}{-0-}$ & $\frac{\frac{3,205}{-0-}}{-0-}$ & $\frac{1112)}{-0-}$
\end{tabular}

FY 1977 INCREMENT

$0 \quad 47,600$

CE 1510

49660

$(000,000)$

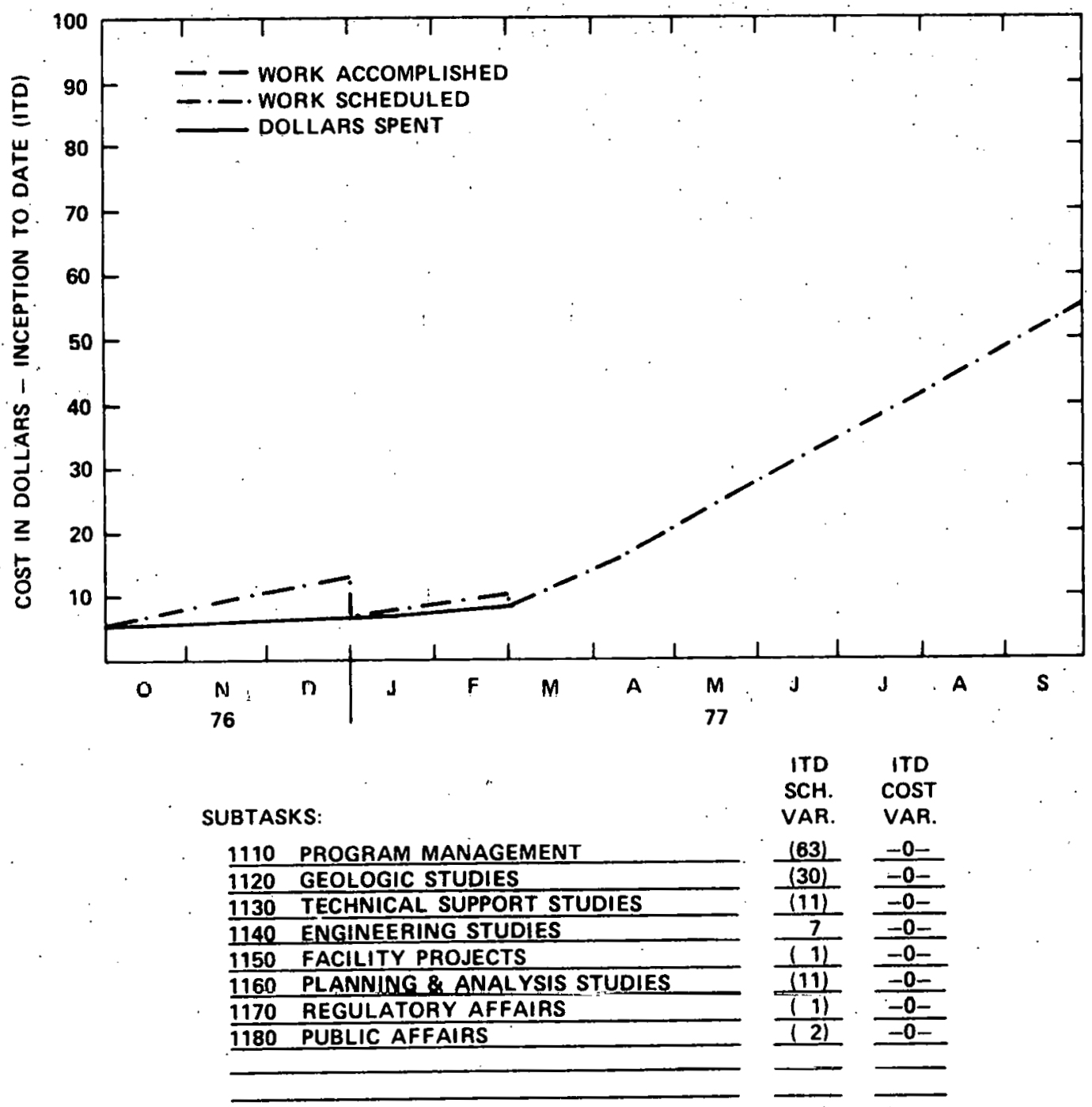

Figure D-1. Sample OWI Status Report

D-2 


\section{APPENDIX E}

\section{COMMITMENT STATUS REPORT}

The Commitment Status Report shows the difference between the anticipated (planned) budget versus the actual committed dollars. The budget dollars are derived from information recorded on the Planning Data Sheet (Figure B-1, Area (6)).

Information for the presentation of actual committed dollars is derived from UCC-ND cost account records sorted by work-order number. The Sample Commitment Status Report, Figure E-1, provides information on the status of commitments in both summary and detail levels 0 and 1 of the Work Breakdown Structure. The graphic portions of the report shows the per cent of budget committed as of the report date. "Time Now" indicates the per cent of the fiscal year that has transpired. 
NATIONAL WASTE TERMINAL STORAGE PROGRAM

ISSUE-DATE: April 1, 1977

OFFICE OF WASTE ISOLATION

PERIOO END: . March 31, 1977

COMMITMENT STATUS REPORT- SUMMARY

PAGE:

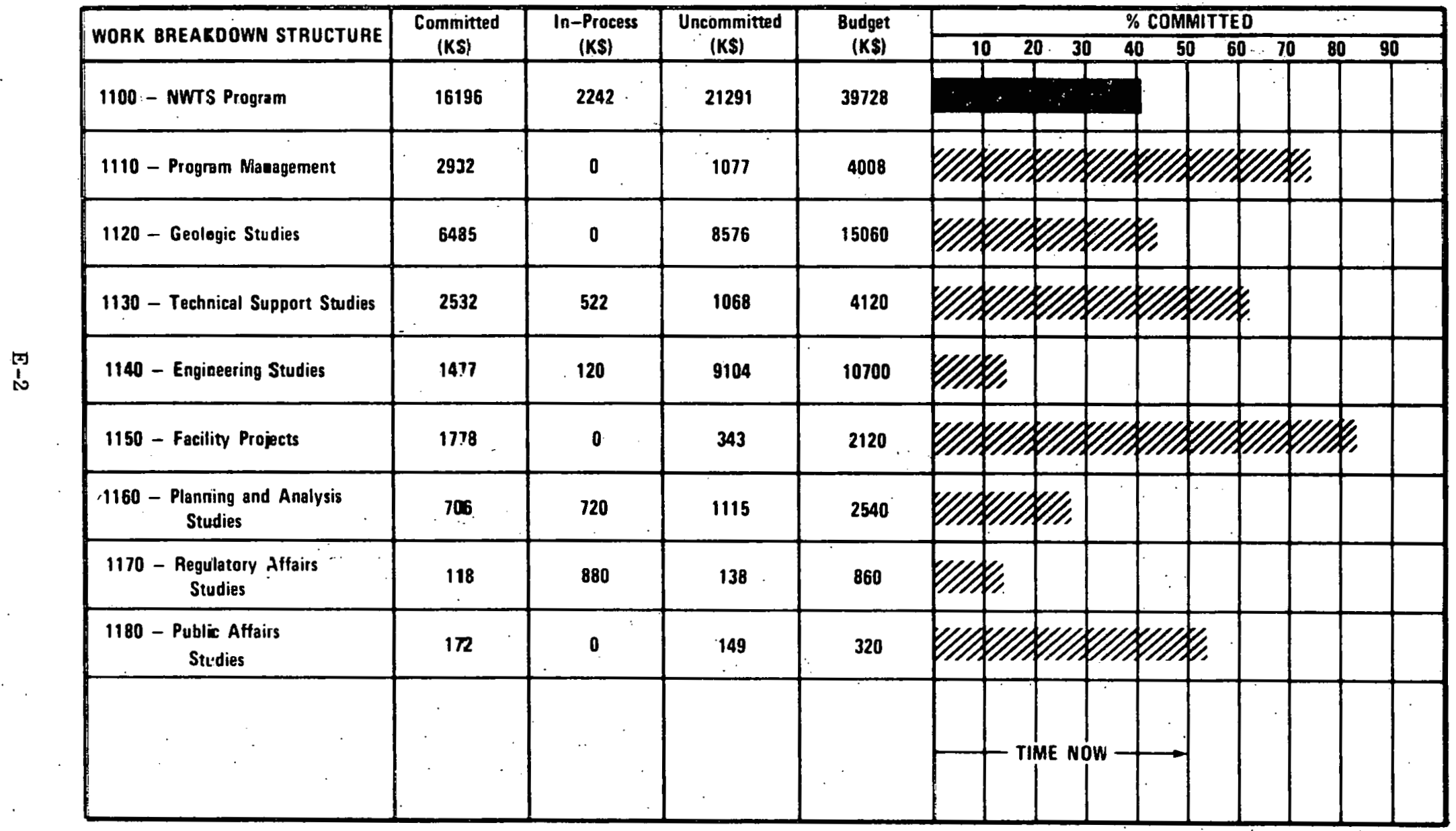

Figure E-1. Sample Commitment Status Report (Page 1 of 2) 


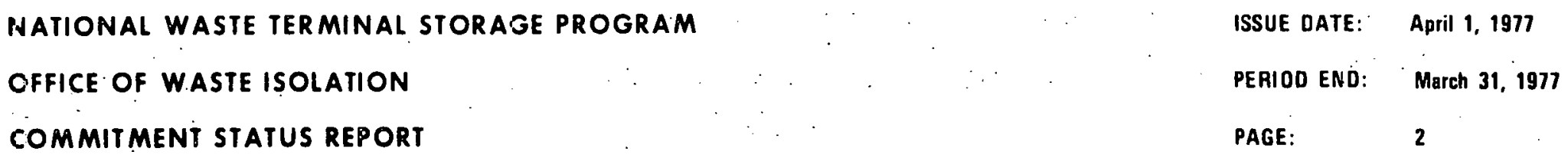

COMMITMENT STATUS REPORT

PAGE: 2

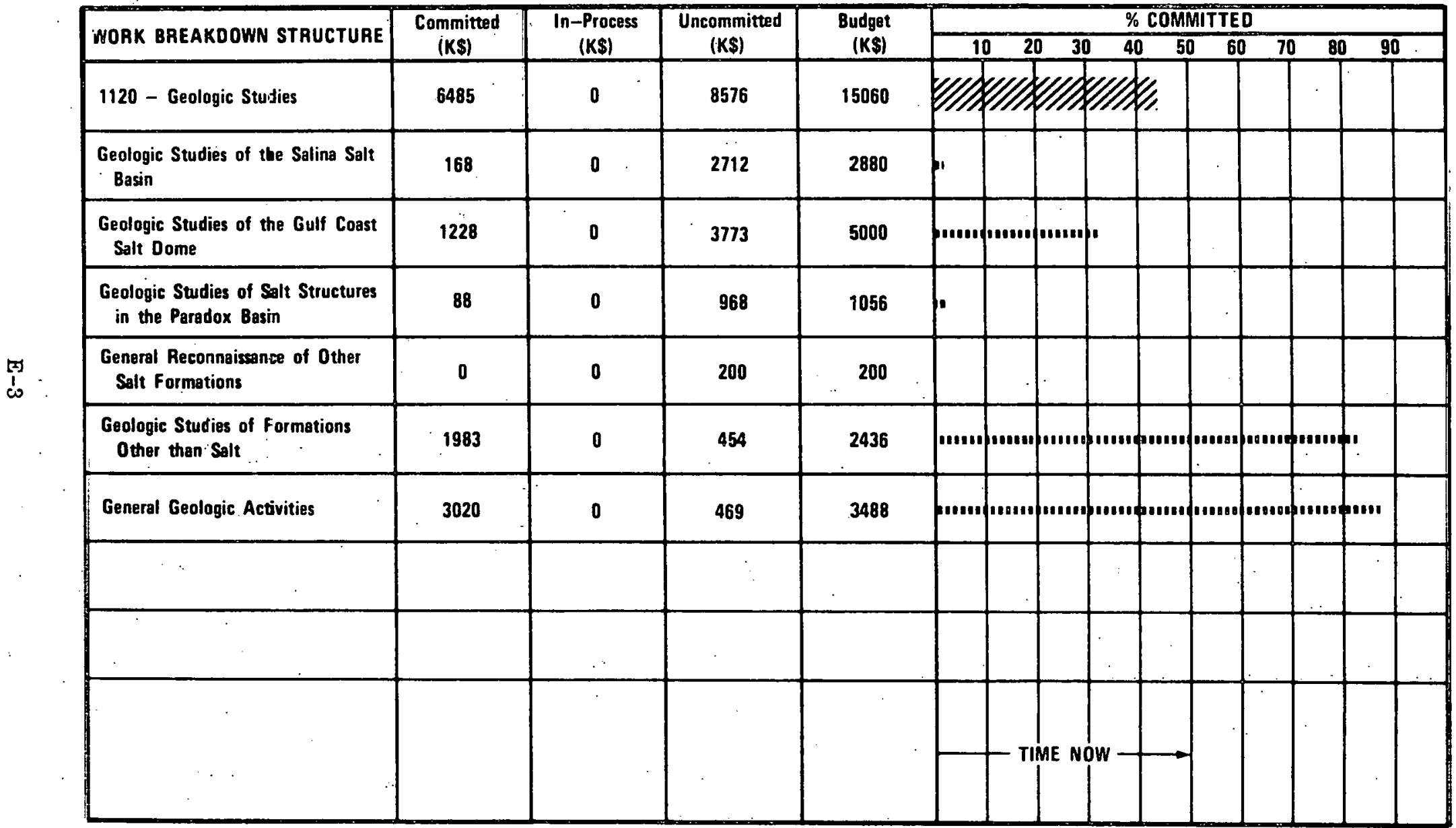

Figure E-1. Sample Commitment Status Report (Page 2 of 2) 
APPENDIX F

SCHEDULE STATUS REPORT

Figure F-1, Schedule Status Report, is an example of the types of required information and possible charting techniques that may be utilized by OWI to report schedule status.

F-1 
SCHEDULE STATUS REPORT

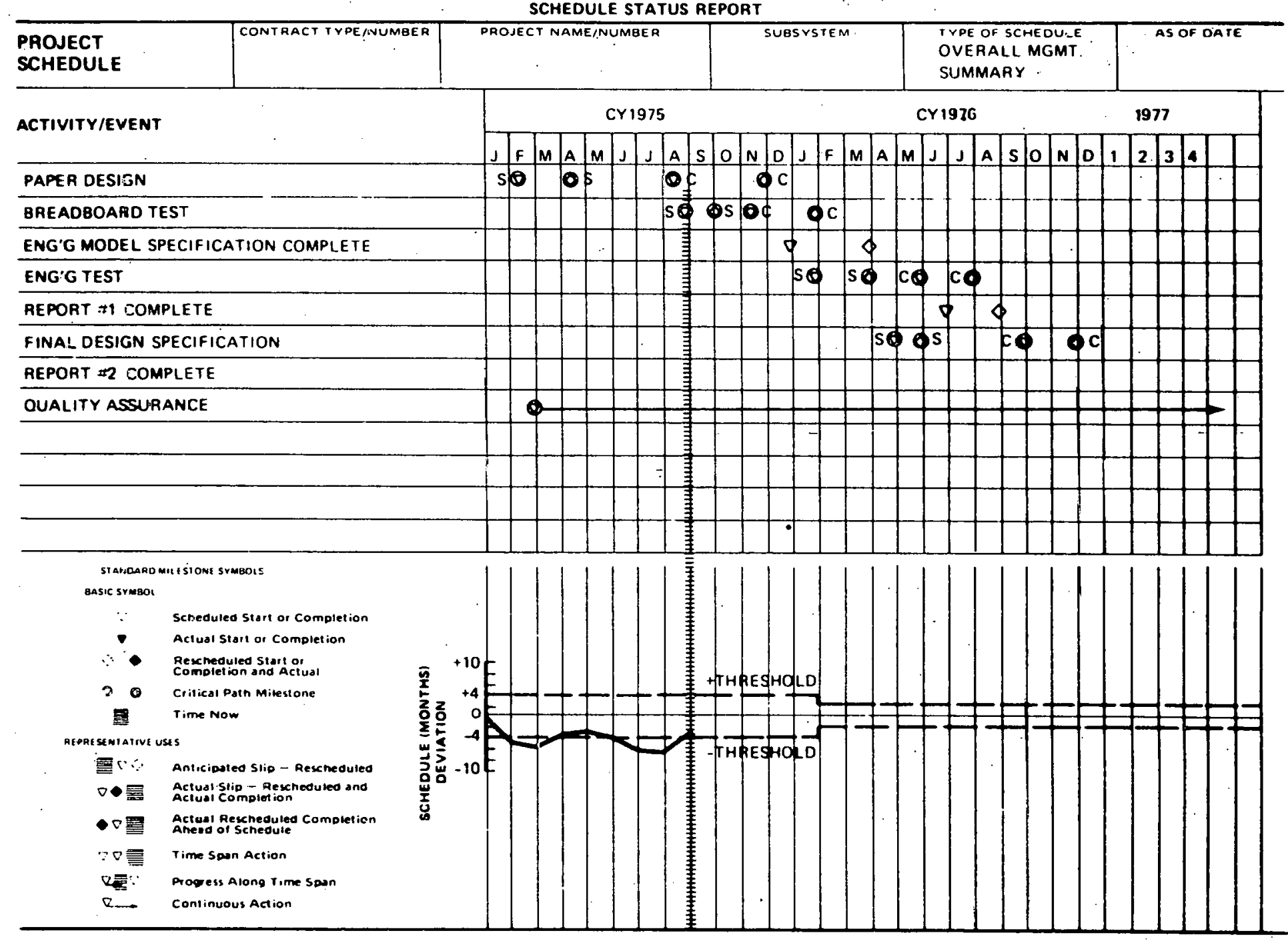

Figure F-1. Schedule Status Report 